\title{
Seawater Monitoring under the Influence of SABESP Sea Outfalls in Baixada Santista (South Coast) and North Coast - São Paulo State - Brazil
}

Silene Cristina Baptistelli | Edward Brambilla Marcellino

DOI 10.4322/dae.2016.012

\section{ABSTRACT}

In order to assess the environmental conditions of the receiving water body, as well as to measure the dispersion of the outfall plume before the construction and during its operation, environment monitoring has been an essential tool. SABESP has been using monitoring programs for decision making and to give reliability in diagnoses and prognoses for sea outfall management. This paper presents a compilation of the main monitoring programs that SABESP has been working on over the last 10 (ten) years (since 2005) in São Paulo coastal regions under influence of several sea outfalls. Through the major monitoring results, the aim of this paper is to discuss the impacts that outfalls have been causing in the coastal area of São Paulo State. In summary, the influence of ocean outfalls in changing the quality of water in Baixada Santista and North Coast is limited mainly at the mixing zone close to the diffuser.

Keywords: environment monitoring programs; environmental impacts; sea outfall

\section{RESUMO}

Os monitoramentos ambientais têm sido essenciais para avaliar as condições ambientais dos corpos d'água receptores e para mensurar a pluma de dispersão antes e durante a operação dos emissários submarinos. $A$ SABESP tem utilizado os resultados dos programas de monitoramento, seja para a tomada de decisão, seja para dar confiabilidade nos diagnósticos e prognósticos dos impactos ambientais. Este artigo apresenta a compilação dos principais programas de monitoramento que a SABESP tem trabalhado nestes últimos 10 anos (desde 2005), na região costeira do Estado de São Paulo sob influência dos vários emissários submarinos. Através da apresentação dos principais resultados desses monitoramentos, o principal objetivo deste artigo é discutir os impactos ambientais que os emissários submarinos têm causado na região costeira de São Paulo. Em resumo, a influência das descargas dos emissários submarinos na costa de São Paulo está limitada à zona de mistura, próxima ao trecho difusor destes emissários.

Palavras-chave: programas de monitoramento ambiental; impactos ambientais, emissários submarinos

Silene Cristina Baptistelli, PhD. Eng. Silene Cristina Baptistell in Hydraulic Engineering USP. SABESP: Sanitation Company of São Paulo State - Brazil, Rua Costa Carvalho, 300 - Alto de Pinheiros São Paulo - SP - Brazil - CEP: 05429-000 - sbaptistelliasabesp.com.br Phone: +55 11 3388-8601.

Edward Brambilla Marcellino, MSc. Eng. Edward Brambilla Marcelino in Hydraulic Engineering USP. SABESP: Sanitation Company of São Paulo State - Brazil 


\section{INTRODUCTION}

In order to assess the environmental conditions of the receiving water body, as well as to measure the dispersion of the outfall plume before the construction and during its operation, environment monitoring has been an essential tool. SABESP has been using monitoring programs and mathematical models for decision making and to give reliability in diagnoses and prognoses for environment and sea outfall management. This paper presents a compilation of the main monitoring programs that SABESP has been working on over the last 10 (ten) years (since 2005) in Baixada Santista (South Coast) and North Coast of São Paulo State. These monitoring programs comprise areas under influence of 5 (five) existing outfalls in Baixada Santista and 2 (two) in North Coast. This paper shows an abstract of seawater parameters.

Metropolitan Region of Baixada Santista is located along São Paulo State shoreline in 160 km length, and comprises Santos (major city), São Vicente, Cubatão, Guarujá, Bertioga, Praia Grande, Mongaguá, Itanhaém and Peruíbe municipalities.

Baixada Santista is characterized as the most dynamic economy of São Paulo coast, supported by harbour activities and industrial complex in $\mathrm{Cu}$ batão city. The region has two inter-regional key importances: urban-harbour-industry in Santos,
São Vicente, Cubatão and Vicente de Carvalho district (Guarujá); and leisure and tourism in the other cities. The region has an ecosystem of paramount importance for economic-environmental approach, like São Vicente, Bertioga and Santos channels.

According to the IBGE statistic institute, the resident population in Baixada Santista is $1,797,500$ inhabitants (estimation of July/2015), living along 2,887 km² (http://downloads.ibge.gov.br/downloads_estatisticas.htm). This region has the population increased up to the double during vacations period. The sewage system coverage rate is $72 \%$ and the treatment of collected sewage is $100 \%$ in Baixada Santista.

The North Coast of São Paulo State comprises São Sebastião, Ilhabela, Ubatuba and Caraguatatuba municipalities. According to the IBGE statistic institute, the resident population in North Coast is 314,926 inhabitants (estimation of July/2015), living along $1,947 \mathrm{~km}^{2}$ (http://downloads.ibge.gov. br/downloads_estatisticas.htm). The sewage system coverage rate is $56 \%$ and the treatment of collected sewage is $100 \%$. Both sea outfalls are placed in São Sebastião channel which is $24 \mathrm{~km}$ length and $6.0 \mathrm{~km}$ average width (see Figure 5). Table 1 lists the main characteristics of the existing sea outfalls in São Paulo coast.

Table 1: Characteristics of the major existing sea outfalls in Baixada Santista and North Coast Obs: pre-treatment using grit chambers, miliscreens and disinfection.

\begin{tabular}{|c|c|c|c|c|c|c|c|}
\hline City & System & $\begin{array}{l}\text { Maximum population } \\
\text { served (inhabitants) }\end{array}$ & $\underset{(\mathrm{m} 3 / \mathrm{s})}{\operatorname{Maximum} \text { flow }}$ & Outfall length (m) & Diameter (m) & Depth (m) & $\begin{array}{c}\text { Pipe } \\
\text { Material }\end{array}$ \\
\hline Praia Grande & Praia do Forte & 253,755 & 1.041 & 3,300 & 1.00 & 12.5 & PEAD \\
\hline Praia Grande & Vila Tupi & 348,635 & 1.047 & 3,300 & 1.00 & 13 & PEAD \\
\hline Praia Grande & Vila Caiçara & 559,103 & 1.400 & 4,095 & 1.00 & 13 & PEAD \\
\hline Santos & José Menino & $1,322,100$ & 7.267 & 4,425 & 1.75 & 10 & $\begin{array}{c}\text { coated } \\
\text { steel } \\
\text { concrete }\end{array}$ \\
\hline Guarujá & Praia da Enseada & 445,858 & 1.447 & 4,500 & 0.90 & 14 & PEAD \\
\hline São Sebastião & Araçá & 21,396 & 0.140 & 1,215 & 0.40 & 17 & PEAD \\
\hline Ilhabela & Itaquanduba & 30,536 & 0.154 & 941 & 0.45 & 36 & PEAD \\
\hline
\end{tabular}




\section{GOALS}

The main goals of this paper are to present the last seven monitoring programs run by SABESP along São Paulo state shoreline, specifically Baixada Santista and North Coast regions, and discuss about sea water quality under influence of the outfalls.

\section{METHODOLOGY}

The primary data collected in shoreline under sea outfalls influence in São Paulo state are shown in a systematized form in this paper. Firstly, monitoring programs are presented showing the location of sampling points, evaluated parameters, and sample quantity/frequency. In the following, major results of monitoring programs are presented. The results are discussed under environmental law and technical aspects of the existing outfalls.

\section{ENVIRONMENTAL MONITORING PROGRAMS AND RESULTS}

In this article 3 (three) works of Baixada Santista and 4 (four) works of the North Coast were selected for presentation. The samples were collected according to recommendations of the Standard Methods for the Examination of Water and Wastewater for each type of analysis. Those programs generated a very large amount of data used for related assessments to individual objectives of each program. This paper presents the compilation of results of some representative parameters of water quality in order to assess the temporal evolution and spatial distribution of the environmental characteristics of the region. The results of four water quality parameters were compared with the limits established by CONAMA Resolution No. 357/05 (BRASIL, 2005), for Class 1 of saline water.

1. Environmental Monitoring Program of the areas under the influence of the outfalls of sewage Santos and São Vicente and Praia Grande, Subsystems 1, 2 and 3 (2005-2006) - ENCIBRA / TECAM / FALCÃO BAUER. (SABESP, 2006b)

The main purpose of the monitoring was to verify the conditions of the area under the influence of the Marine Outfall of Santos/São Vicente and Praia Grande, assessing the impairment of quality of sea water, associated to discharge of effluent through these outfalls. Samples were collected in six campaigns in the sea water at three depths (surface, average depth and bottom) to perform the following analyzes: temperature, salinity, DO, TOC, oils and greases, nitrate, nitrite, ammonia nitrogen, Turbidity, soluble phosphate, Total phosphorus and fecal coliforms and chlorophyll-a.

Figure 1 shows the location of the sampling points of the sea.

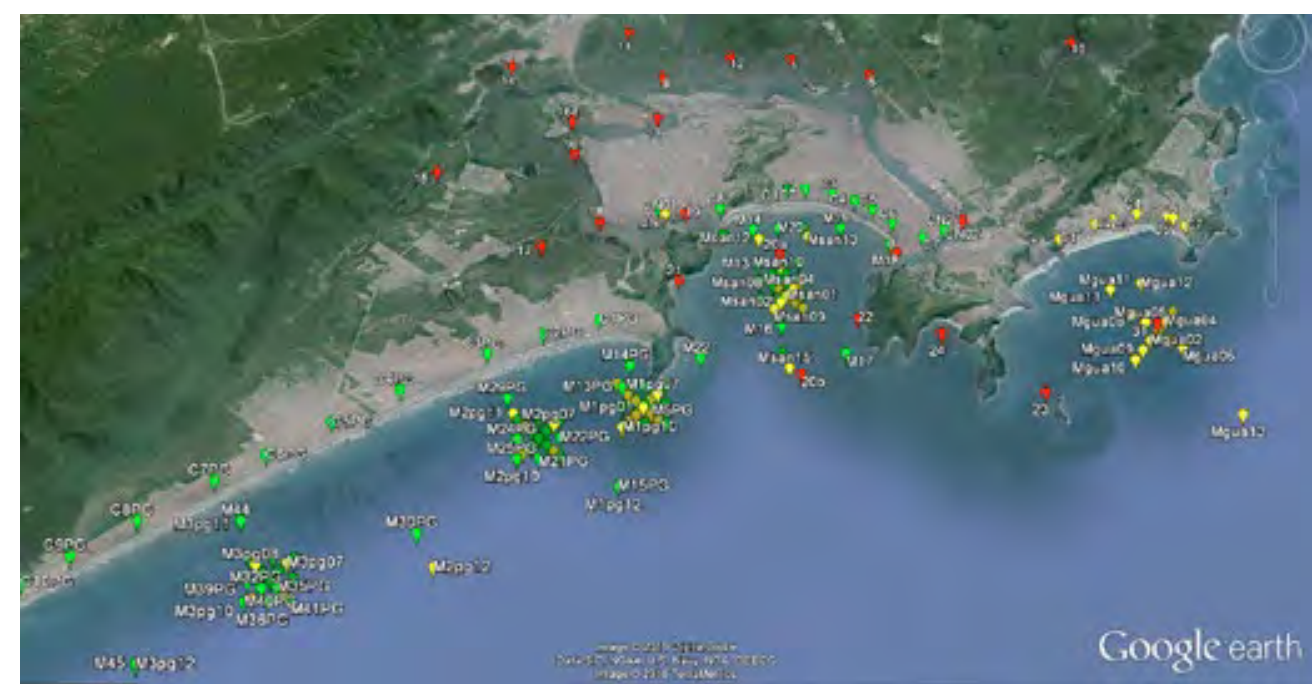

Figure 1: Location of sampling points in Baixada Santista - SABESP, 2006 (green); SABESP, 2013a (red); - SABESP, 2013b (yellow) 
According to SABESP (2006), in Santos, for 5 (five) sampling campaigns values were identified over the limit the use of class: TOC ( $25 \%$ of samples), nitrate (2\%), nitrite (1\%), and ammonia (2\%) Total phosphorus ( $42 \%)$ and fecal coliforms (6\%). Considering all data, TOC and Total phosphorus were the parameters that were most in disagreement with the limits of CONAMA 357/05, and occurred over the limit values spread over all monitored points, including the control point. Moreover, nitrogenous compounds and fecal coliforms were rarely above limits, and into the mixing zone.

Considering the five campaigns between 2005 and 2006 to the emissaries of Praia Grande, were identified values above the limit for the analysis of TOC (38\% of the samples in PG1, 17\% PG 2 and 1\% PG3); Nitrate (1\% in PG2 and PG3); Nitrite (2\% and 1\% PG1 PG2); Total Phosphorous (47\% and $34 \%$ PG1 and PG2) and fecal coliforms (0.4\% PG1). Considering all data, TOC and Total phosphorus were the parameters that were most in disagreement with the limits of CONAMA 357/05, and occurred over the limit values spread over all monitored points, including the control point. Moreover, nitrogenous compounds and fecal coliforms were very few times above the threshold, and within the mixing zone.

2. Quality Monitoring Marine Water, Sediment and Organisms in the estuary of Santos and São Vicente and coastline and Adjacent areas in the cities of Bertioga, Guarujá, Cubatão, Santos, São Vicente and Praia Grande (2010 2013) - ENCIBRA / TETRATECH / TECAM / JICA (SABESP, 2013a)

This monitoring program is included in the scope of the Environmental Recovery Program for the Baixada Santista (RMBS) - Clean Wave Program, the Government Japanese Cooperation Agency JICA and aimed to assess the marine water quality in Baixada Santista with the improvements implemented by the works of Onda Limpa program. Figure 1 shows the location of the sampling points.
Ten sampling campaigns were carried out and the evaluation of results of Santos Estuarine region was divided into three compartments: (a) Estuary of Santos and Bertioga Channel; (b) Estuary of São Vicente and (c) Santos Bay. In the Estuary of São Vicente there was a very large percentage of non-compliance. Figures 2 show the spatial distribution of mean values of total phosphorus in the water sampling points in the estuary of São Vicente.

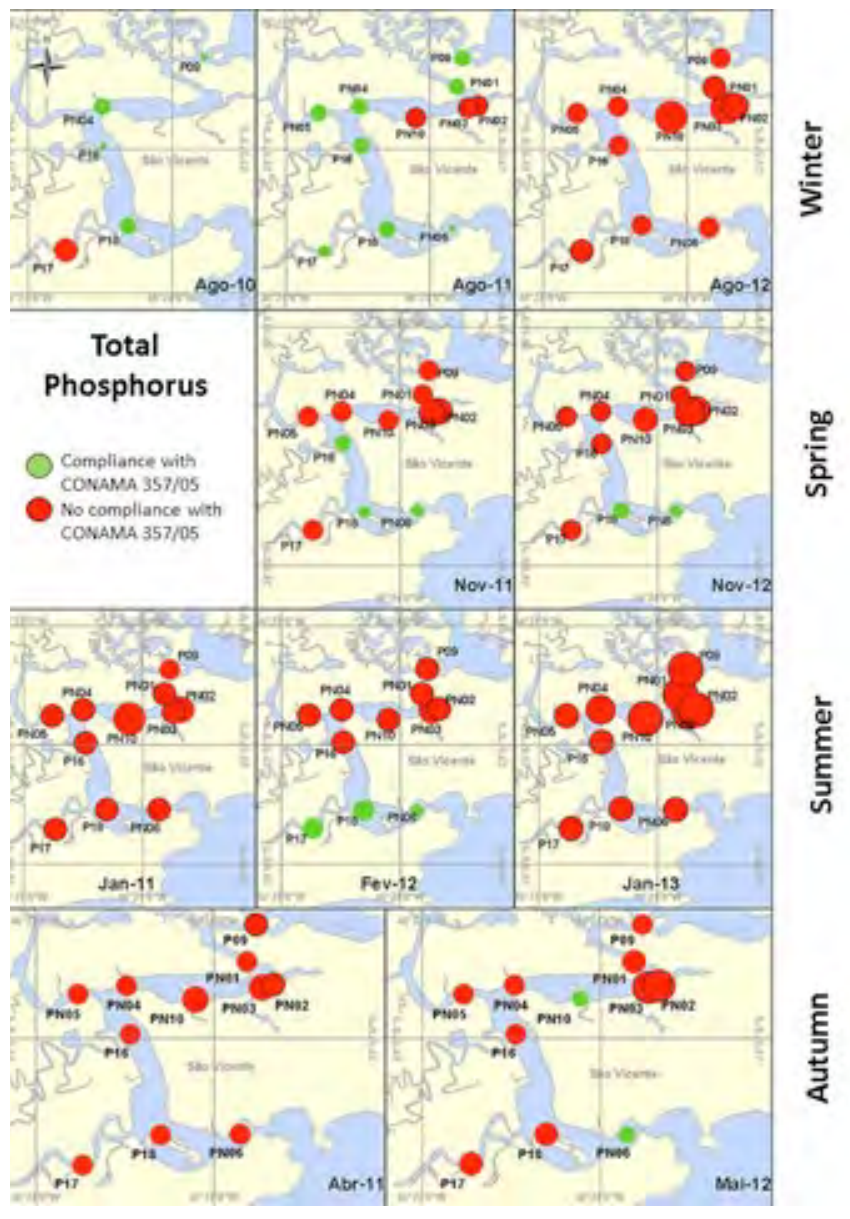

Figure 2: Average values of total phosphorus in the water sampling points in the estuary of São Vicente, all sampling campaigns.

The evaluation of the waters of the Bay of Santos was conducted in five sampling points. The largest number of parameters and the highest percentages of non-conformities in the Bay of Santos were verified in the summer campaigns. Concentration of coliforms above the limit of CONAMA $357 / 05$ were verified only at the point located at 
the exit of Santos outfall, and therefore into the mixing area, the place where the default class is not reached.

3. Monitoring of water quality under the influence of ocean outfalls of sewage systems Sanitary Guarujá, Santos and São Vicente and Praia Grande. (2011 - 2012) - DTA. (SABESP, 2013b)

Monitoring had quarterly campaigns for the sea. The same parameters of previous campaigns were analyzed. In this program were carried four sampling campaigns, with samples at 3 depths. In the Santos bay were sampled 15 points; in Praia Grande were 36 points and Guarujá 13 points.

Figure 3 presents the spatial distribution of Enterococcus concentrations and it shows that close to the emissary exit the concentrations were higher than in the more distant points. It is also shown that in the points near the coast, especially near São Vicente, higher concentrations are found. There is a significant contribution of contaminants of Santos and São Vicente channels that contribute to the deterioration in water quality near the coast.

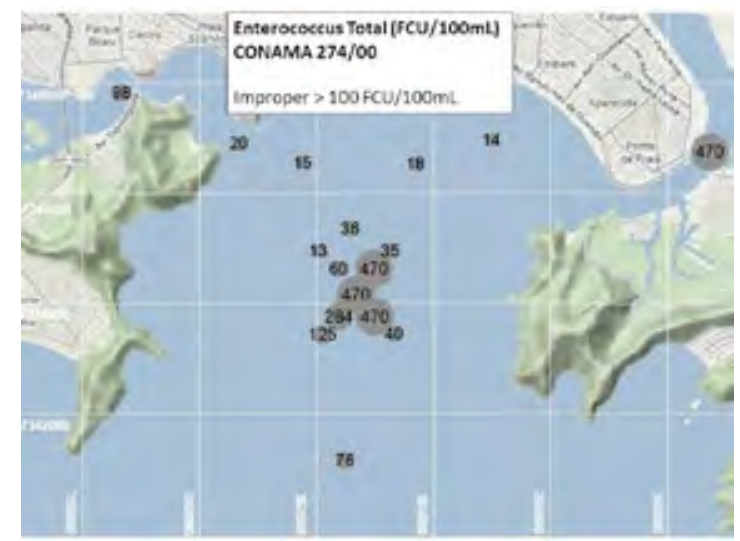

(a)

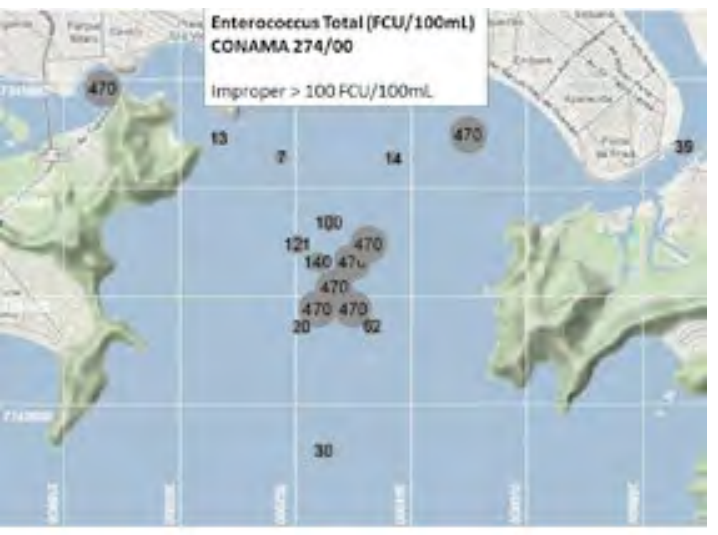

(b)

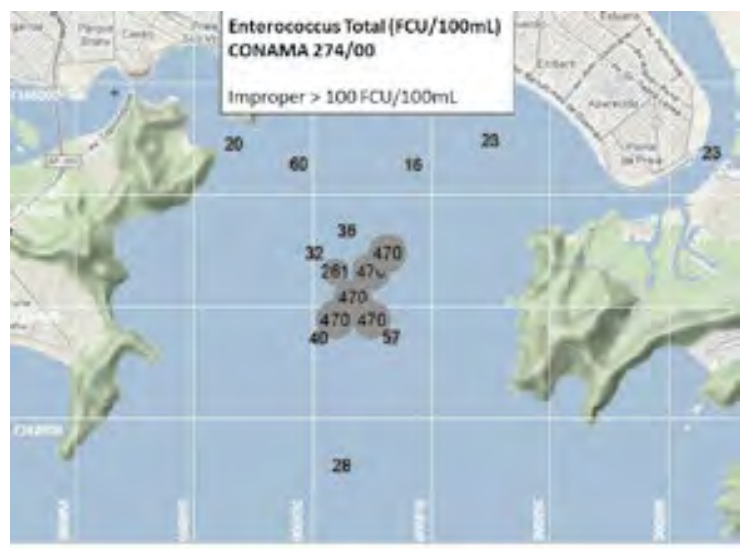

(c)

Figure 3: Distribution of Enterococcus Total - Surface (a) Half height (b) Bottom(c). (SABESP, 2013b

Figure 4 shows the compliance rate between the monitoring results and the water quality standard of CONAMA 357/05 legislation of the four major water quality parameters. The results of Santos and Praia Grande comprehend the period 20052013 and Guarujá cover the period 2011-2012. 


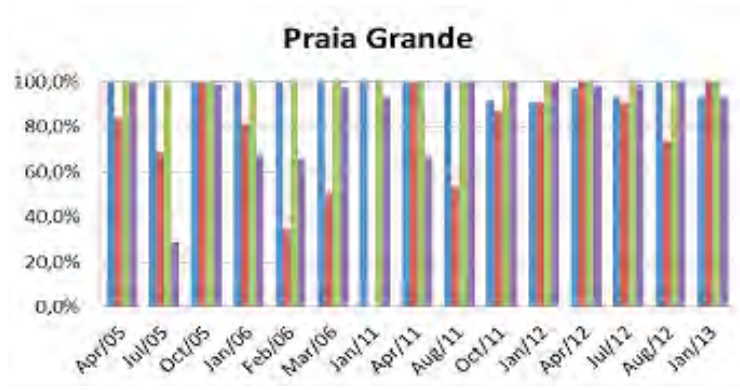

Santos

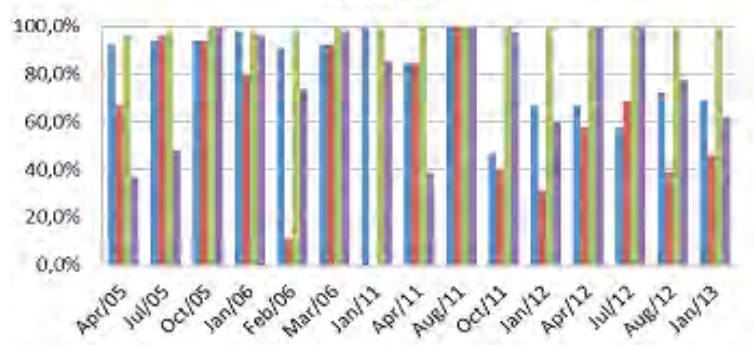

\section{Guarujá}

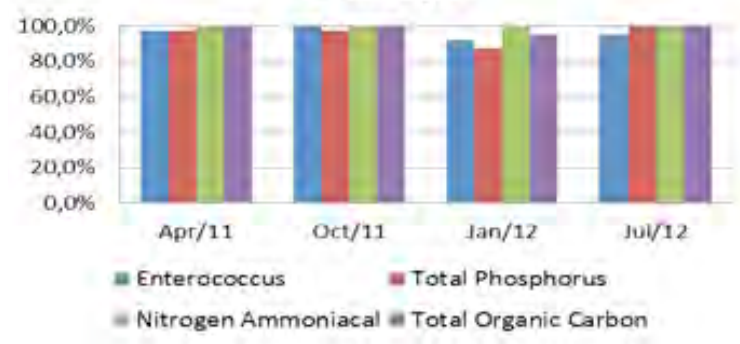

Figure 4: Results of seawater quality compliance with CONAMA 357/05 for Praia Grande, Santos and Guarujá outfalls.

The results show $100 \%$ compliance in the campaigns of 15 ammoniacal nitrogen monitoring to Praia Grande and Guarujá, and $99.4 \%$ for Santos. The results show for Total Phosphorus $60.5 \%$ compliance for Santos and 74.2\% for Praia Grande and COT 78.3\% compliance for Santos and $87.2 \%$ for Praia Grande. For fecal coliforms and Enterococcus results show $81.8 \%$ compliance for Santos, 97.8\% to Praia Grande and $96.2 \%$ for Guarujá. The results indicate that the quality of the sea water is not being adversely affected by the outfall discharge, except within the mixing zone.
4. Environmental characterization of São Sebastião channel under Itaquanduba sea outfall influence area. Ilhabela municipality - Sep. and Dec./2005 - ASA (SABESP, 2006a)

The main target of this monitoring program was the environmental characterization of the influence area before the construction of Itaquanduba sea outfall, which started to run in 2010. Monitoring involved 2 (two) sea monitoring including physical, chemical and microbiological parameters, phyto and zooplankton, benthos, water toxicity and sediments as well as fish community. Sample collect were done in 19 (nineteen) sea sampling points. Figure 5 shows the sampling points in sea water, beach and creek around the area under influence of Araçá and Itaquanduba sea outfalls. Environmental monitoring of São Sebastião channel during operations of Itaquanduba Ocean Disposal System - Ilhabela municipality - 2012/2013 - FALCÃO BAUER (SABESP, 2013c) were carried out after Itaquanduba outfall started the operation in order to evaluate the efficiency of the system by comparing the sea water quality before and after the inauguration.

The monitoring involved 4 (four) sea campaigns carried out in October 2012, January, April and July 2013, including physical, chemical and microbiological (coliform and enterococcus) parameters, phyto and zooplankton, benthos, water toxicity and sediments. Sampling were done in 10 (ten) sea sampling points, 2 (two) in the beach, 2 (two) in the creeks and monthly samples from affluent and effluent of pre-conditioning plant.

The seawater evaluation of September and December 2005 (SABESP, 2006a), before the sea outfall operation, shows that results of seawater quality were in normal conditions, except regarding the following parameters that exceeded the standard limits: phosphorus, turbidity, oil \& grease and dis- 
solved oxygen (DO). In terms of fish evaluation, no deformity or physical morphologic/morphometric modification and atypical odor were observed.

Environmental monitoring carried out from $\mathrm{Au}$ gust 2012 to July 2013 (SABESP, 2013c), after the outfall installing and operation, assign that results of seawater quality were in normal conditions, particularly for microbiological aspects, except regarding the following parameters: turbidity, DO and total organic carbon (TOC). Creeks water quality revealed high concentration of coliform and enterococcus.

Figure 6 shows the compliance rate between the monitoring results and the water quality standard of CONAMA 357/05 law before and after 2010, when Itaquanduba sea outfall started the operation. The results of the four major water quality parameters show $100 \%$ compliance in the last two monitoring campaigns, which indicates that seawater quality is not being negatively affected by the outfall discharge.

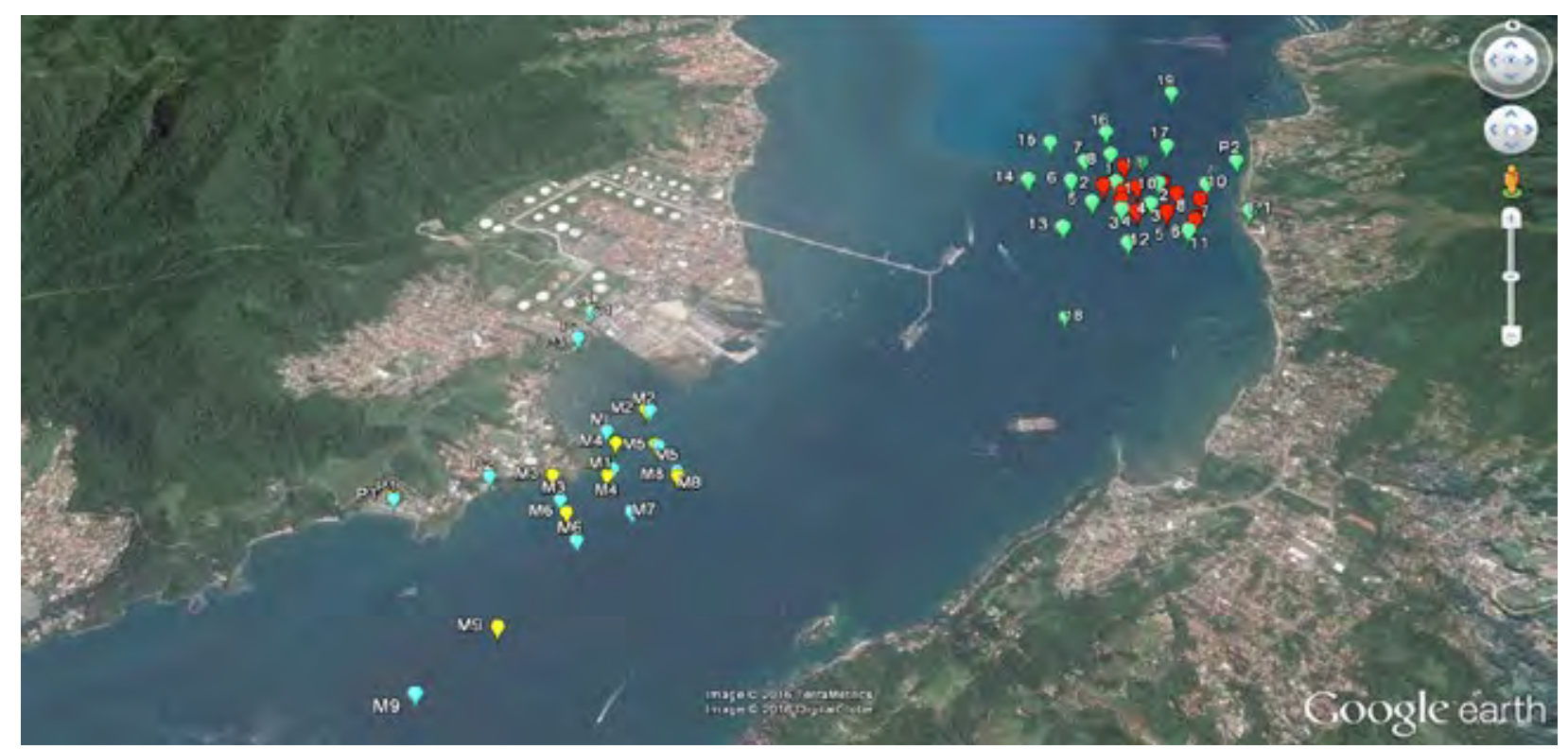

Figure 5: Location of the sampling points in São Sebastião channel. Itaquanduba outfall - SABESP, 2006 (green) and SABESP, 2013c (red); Araça outfall - SABESP, 2012 (blue) and SABESP, 2015 (yellow)

5. Environmental Monitoring under Araçá sea outfall influence area - São Sebastião municipality - Jan/Jul/2012 (SABESP, 2012)

Monitoring program carried out during this period evaluated the environmental conditions in the area under influence of sea outfall before its 150 meters extension increase in 2014.
The monitoring involved 2 (two) sea campaigns including physical and chemical quality in water column and benthos. Sample collect were done in 9 (nine) sea sampling points in 2 (two) depths in January and July/2012, 3 (three) beach stations as well as 1 (one) creek and samples from affluent end effluent of pre-conditioning plant along six months. 
6. Environmental monitoring under Araçá sea outfall influence area - São Sebastião municipality - Jan/Fev/Abr/2014 (SABESP, 2015)

Monitoring carried out during this period evaluated environmental conditions in the influence area of the sea outfall before, during and after the installation of 150 meter pipe extension at the end of the existing sea outfall in 2014. The monitoring involved 6 (six) sea campaigns including physical, chemical and microbiological quality in water column and benthos. Sample collect were done in 9 (nine) sea sampling points in 2 (two) depths in January and July/2013/2014/2015, 3 (three) beach sampling points as well as 1 (one) creek and samples from affluent end effluent of pre-conditioning plant along six months.

Environmental monitoring carried out in January and July 2012 (SABESP, 2012), before the 150 meters outfall extension, show that results of seawater quality were in normal conditions, except regarding DO and chlorophyll-a parameters. On the other hand, creeks water quality revealed high concentration of coliform and enterococcus, which affected the bathing water quality of the beach nearby.

The environmental monitoring of January and July 2013, 2014 and 2015 (SABESP, 2015), some of them after the pipe extension in Apr/2014, indicates that results of seawater quality were in normal conditions, except for DO, phosphorus and total organic carbon (TOC). Bacterial parameters exceeded legal standard in January/2015 marine campaign and in all creek and beaches water campaigns.

Figure 6 shows the compliance rate between the monitoring results and the water quality standard of CONAMA 357/05 law before and after 2014, when Araçá sea outfall was extended in 150 meters and the discharge depth turned from 7 meters to 17 meters. The results of the four major water quality parameters show more than $80 \%$ compliance in every monitoring campaign. However, the improvement with a deeper discharge after the pipe extension in 2014 had no expected results and indicates that seawater quality is supposed to be negatively affected by other pollution sources such as the creeks, non-point loads and harbor activities.
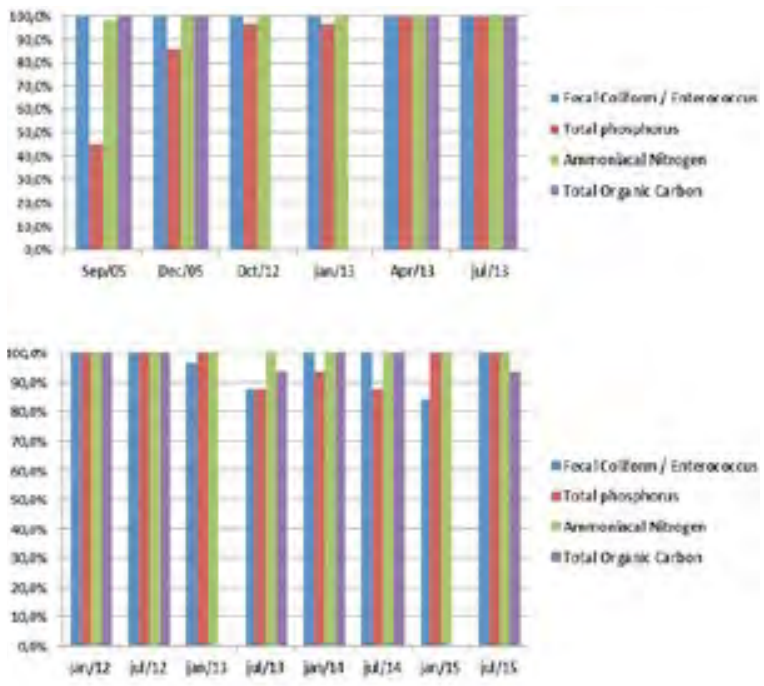

Figure 6: Results of seawater quality compliance with CONAMA 357/05 law for Itaquanduba outfall (upper chart) and Araçá outfall (lower chart)

\section{DISCUSSION}

In this section the main results of the monitoring are discussed by ocean outfalls and its respective area of influence:

\section{Santos Sea Outfall:}

From the results of the presented monitoring the water quality in estuary of São Vicente and Santos Bay is heavily influenced by the input of nutrients and organic compounds into the system, especially in times associated with intense rainfall and increasing floating population in Baixada Santista. The presence of fecal coliforms and enterococci in estuary waters demonstrates the inadequate discarding of domestic sewage in the estuarine environment. Natural and artificial channels receive clandestine wastewater as well as the rain- 
water and urban drainage, which also contribute to contamination. The outfall is not the only and does not the biggest source of contribution for total phosphorus in the bay of Santos. Regarding Enterococci, the results in the bay of Santos indicate $100 \%$ compliance with the limit, in points outside the mixing zone. Inside the mixing zone the results demonstrate good dispersive capacity of the plume even within the bay.

\section{Praia Grande Sea Outfalls:}

Compared to the Bay of Santos, Praia Grande has a lower trophic level. Due to the high hydrodynamic, this region has faster recover capability from ocean outfalls discharges. According to the monitoring carried out, it can be said that Praia Grande Outfalls are affecting very little the water quality of the area outside the mixing zone of the emissaries.

\section{Guarujá Sea Outfall:}

Only 5 out of the 39 water samples analyzed in seawater surrounding the Guaruja outfall showed higher concentration to the limit of CONAMA $357 / 05$ for total phosphorus, and in 2 points the concentration of total organic carbon exceeded the limit. It may not say that Guaruja outfall is impacting on water quality in its surroundings considering the quality standards of CONAMA resolution 357/05.

\section{Araça Sea Outfall - São Sebastião:}

An overall approach on water quality under influence of Araçá sea outfall indicates that although bacterial concentration around outfall discharge comply with the legal standard (over $90 \%$ of the samples), raw sewage from communities not served by the sewage system strongly impacts Mãe Izabel creek and cause fecal pollution on surrounding beaches in front of the sea outfall. Regarding seawater quality, despite the additional extension in 150 meters of the sea outfall in 2014, making the discharge 10 meters deeper, no re- duction in parameters concentrations has been observed so far, which indicates that only diffuser dilution increase is not enough and seawater quality depends on other organic sources.

\section{Itaquanduba Sea Outfall - Ilhabela:}

In general seawater quality under influence of Itaquanduba sea outfall indicates that bacterial concentration around outfall discharge comply with the legal standard $(100 \%$ of the samples in the last two campaigns), and as a rule, an improvement in water quality was observed after the collecting, treatment and disposal of sewage was completed in the nearby watershed. However reminiscences of raw sewage from illegal connections and communities not yet served by sewage system strongly impacts creeks and cause fecal pollution on surrounding beaches in front of the sea outfall, especially during the rains, which were supposed to eventually affect seawater quality in terms of carbon and suspended solids. Nutrient parameters complied $100 \%$ in the last two campaigns.

\section{CONCLUSION}

Environmental monitoring of the areas under the influence of SABESP outfalls, which were conducted between 2005 and 2013 were quite comprehensive and complex. Based on these results, some of the conclusions are as follows: (i) regarding the results of Enterococci in seawater, it can be concluded that there has been no return to the beaches of the effluent released by the outfalls. However, the collection results in streams that reach beaches showed high values of coliforms, indicating that pollution control measures should be made on these streams, increasing the collection rate in the city, diffuse pollution control as well as illegal connections control; (ii) For total phosphorus parameters, the results indicate that the outfalls have not been the only contribution source in the region of Baixada Santista; (iii) The results show almost $100 \%$ compliance in all mon- 
itoring campaigns for Ammonia Nitrogen. In summary, the influence of ocean outfalls in changing the quality of seawater in Baixada Santista and North Coast is limited at the mixing zone near the diffuser, and that far away from this area the effects are not noticeable.

\section{REFERENCES}

BRASIL. Resolução n. ${ }^{\circ}$ 357, de 17 de março de 2005. CONAMA. 2005

SABESP. Caracterização Ambiental do Canal de S. Sebastião na Área de Influência do Em. Sub. de Itaquanduba, Ilhabela. ASA. 2006a

SABESP. Monitoramento Ambiental da Área sob Influência do Em. Sub. Dos SES de Santos/S. Vicente e PG. ENCIBRA /FALCÃO BAUER/TECAM. 2006b.
SABESP. Serviços de Monitoramento Ambiental da Área de Influência do Em. do Araçá - S. Sebastião (SP) ASA. 2012

SABESP. Monitoramento da Q̣ualidade da Água Marinha, Sedimentos e Organismos no Estuário de Santos e S. Vicente e nas Zonas Litorâneas e Adjacentes de Bertioga, Guarujá, Cubatão, Santos, São Vicente e Praia Grande. Consórcio Encibra /TetraTech/ TECAM. 2013a.

SABESP. Relatório de integração do Monitoramento da qualidade das águas e dos sedimentos da Disposição Oceânica dos Em. Sub. e dos esgotos afluentes e efluentes das EPCs dos SES do Guarujá, de Santos e S. Vicente e da PG. DTA. 2013b.

SABESP. Monitoramento Ambiental do Canal de S. Sebastião no Entorno do Emissário de Itaquanduba - FALCÃO BAUER. 2013c. SABESP. Monitoramento Ambiental da Área de Influência do Emissário Submarino do Araçá, São Sebastião - DTA. 2015. 